\title{
Allocation of grassland, livestock and arable based on the spatial and temporal analysis for food demand in China
}

\author{
Huilong LIN (凶), Ruichao LI, Yifan LIU, Jingrong ZHANG, Jizhou REN \\ State key Laboratory of Grassland Agro-ecosystems, College of Pastoral Agriculture Science and Technology, \\ Lanzhou University, Lanzhou 730020, China
}

\begin{abstract}
To explore the distribution of food demand and the projected trend in future food demand in China, this paper analyzed the change in current (1998-2012) percapita demand for grain, grain-consuming and herbivorous livestock products, and predicted the food demand in 2020. The results indicated that in 1998-2012, the national percapita consumption of grain ration declined by about $36.66 \%$, and the per-capita consumption of grain-consuming and herbivorous livestock products increased by about $48 \%$ and $34.09 \%$, respectively. The grain-consuming livestock products have become the primary source of both calories and protein for consumers. The proportion of herbivorous livestock products in consumer diets has increased steadily and there has been huge potential in substituting beef and mutton for pork in this dynamic market. The demand for food in different regions of China is highly variable, which is important for planning grassland agriculture development and ensuring food safety. The demand for grain, and grain-consuming and herbivorous livestock products will increase by about $3.3 \%, 20 \%$ and $14 \%$ respectively by 2020 . Based on the food demand and trend in the development of grassland agriculture, the 31 regions in China are divided into three priority groups for grassland agriculture development.
\end{abstract}

Keywords arable land equivalent unit (ALEU), food equivalent unit (FEU), food security, grassland agriculture, time trend prediction

\section{Introduction}

Food security was proposed as a priority by the FAO in 1974 when it established the Committee on World Food Security. The early definition simply stated 'to ensure that any person can have enough food for survival and health in

Received November 22, 2016; accepted December 25, 2016

Correspondence: linhuilong@1zu.edu.cn any place'. With the continuous improvement in theory and practice, the concept of food security has been expanded to include nutrition security, i.e., any person at any time should be able to consume a sufficient quantity and variety of nutritious and safe food to meet their dietary needs and food preferences ${ }^{[1]}$. Given that the traditional staple food in China is grain, over a long period the concept of food has been largely equivalent to grain, so food security has been misunderstood as grain security ${ }^{[2-4]}$. Since Chinese reform and opening up, the consumption of food by residents has undergone significant change, with consumption switching from largely plant-based foods (such as grain) to include considerably more livestock products. This trend in demand for food diversification has been quite conspicuous ${ }^{[5,6]}$ and over the last two decades, the per capita consumption of grain has decreased by about $44 \%$, while the consumption of livestock products has increased by more than $90 \%{ }^{[7]}$. Therefore in this context, to study grain security alone would be highly lopsided. In keeping with the international nutrition security research dynamic, livestock products have become an important part of research on food security, and, therefore, the concept of food security in China should also focus on its wider meaning ${ }^{[8-10]}$.

At present, regular consumption of food in China includes grain, pork, poultry, eggs, beef and mutton, which can be divided into the grain ration, grainconsuming livestock products (pork, poultry and eggs) and herbivorous livestock products (beef and mutton). The grain ration and grain-consuming livestock products are the most important components of grain demand. Due to the overlap in consumption of grain between people and grain-consuming livestock, however, the intensified competition between these uses has become more serious as the demand for grain-consuming livestock products has increased sharply in recent years. Herbivorous livestock can make use of forage and other plant materials which humans cannot directly consume, and does not create a pressure on grain production. Over the years, research on the development of grassland agriculture to ensure food 
security has developed two key aspects. One has been to demonstrate the rationality and necessity for transforming traditional agriculture practices and developing more grassland agriculture ${ }^{[11-21]}$. The second has been to estimate the grassland agricultural production potential ${ }^{[22]}$. These two aspects of the research have become increasingly mature, although further research on how to develop grassland agriculture is needed. The question of how to develop grassland agriculture involves two important aspects: time and space. Grassland agricultural development cannot be accomplished in one step. It takes time to determine how much area of cultivated grassland and/or pasture-crop rotation should be added each year. Due to the heterogeneity among regions in China, the strategy as to how and to what extent grassland agricultural development occurs should be different at a provincial level. The temporal and spatial distribution of grassland agriculture needs to be confirmed and matched against the actual provincial demand. The priority for grassland agriculture development should be determined in each region based on the actual food demand and the forecast of future food demand.

Grassland agricultural development is complex and needs significant system engineering. Therefore the first purpose of this study was to analyze the changes in percapita food demand at different times for the selected major foods (grain ration, grain-consuming and herbivorous livestock products) using the food equivalent unit $(\mathrm{FEU})^{[23]}$ and the arable land equivalent unit (ALEU) ${ }^{[22]}$ as parameters. The second purpose was to predict the future demand and quantity of various kinds of foods, using a time trend prediction method ${ }^{[24]}$ for each region. The final purpose was to formulate a potential short-term plan for development of grassland agriculture in China for 2020 , based on the food demand at a provincial scale.

\section{Materials and methods}

\subsection{Data acquisition}

The data for food consumption per capita among urban and rural areas in 31 regions (including autonomous regions and municipalities directly under the central government, except Hong Kong, Macao and Taiwan) were sourced from the China Statistical Yearbook, China Rural Statistical Yearbook and the corresponding provincial statistical yearbooks from 1998 to 2013. Provincial urban and rural population data was not included in the China Statistical Yearbook of 2003, so data from Lin's research ${ }^{[25]}$ was used for that year.

Quantities of fed grain for producing a unit of pork, poultry, eggs, beef or mutton were sourced from the Outlook of New Century China Agriculture - Agriculture and Rural Economic Development the First Ten-year Plan Assembly of The Ministry of Agriculture ${ }^{[26]}$. The quantity of forage needed to produce a unit of beef or mutton was sourced from $\operatorname{Ren}^{[27]}$. The amount of high quality forage legume replacing fed grain was obtained from $\mathrm{Li}^{[11]}$. The arable land equivalent of provincial pasture-crop rotation per unit area of cultivated land and conversion of natural grassland into cultivated grassland was sourced from Ren and $\operatorname{Lin}^{[22]}$

\subsection{Methods}

\subsubsection{Comparing the per-capita food demand in 1998 and} 2012

The overall difference in per-capita food demand was compared between 1998 and 2012 at national and provincial scales. The results were plotted with ArcMap 9.0 (Environmental Systems Research Institute, Redlands, CA, USA). It is important to note that different types of food contain different quantities of calories and proteins and provide consumers with different nutrition, thus the quantities are not directly equivalent. Therefore, the food equivalent unit $(\mathrm{FEU})^{[23]}$ was used to convert different types of food consumed to provide equivalence so they could be compared and summed (Table S1).

\subsubsection{Predicting food demand in 2020}

Based on the data for per-capita consumption of grain ration, and grain-consuming and herbivorous livestock products and the population in the 31 regions from 1998 to 2012 , trend prediction models were established to forecast the per-capita consumption of all foods and the population in 2020 , to calculate total food demand by multiplying the per-capita consumption of all foods and population for each region (Table S2).

\subsubsection{Designing a new agricultural construction for China}

First, the arable land equivalent 'red line' was calculated for each region. The arable land equivalent 'red line' was a safety limit of minimum arable land to meet the food security. The demand for grain ration in the regions and the amount of feed grain needed to produce grain-consuming livestock products were added to obtain the total grain demand in 2020. The development of grassland agriculture in the regions to produce grain-consuming and herbivorous livestock products was estimated and the amount of forage required for livestock products was determined. The demand for grain and forage in terms of demand for food equivalent was converted to arable land equivalents. The provincial arable land equivalent amounts are called the 'red line' because the estimates are the minimum arable land equivalents needed to just meet consumer demand for food.

Second, the actual area of arable land required to meet the grain demand in each region was obtained by 
determining the actual area of arable land, grass-crop rotation and cultivated grassland in each region by using the provincial arable land equivalent 'red line' divided by the ALEU in each region. If the existing arable land resources could not meet the demand for cultivated land, the deficit needs to be made up with land from other regions. As forage not only comes from pasture but also from cultivated grassland or pasture-crop rotation, therefore, the comparison of grassland resources and arable land resources in each region was made, and the following scenario for a new agricultural construction was established. If the grassland area is more than twice the cultivated area, the ratio of pasture-crop rotation to cultivated grassland would be 3:7. If the proportion of grassland area is less than twice the area of arable land, the ratio of pasture-crop rotation and cultivated grassland would be 5:5 in that region. If the area of arable land is larger than grassland, the ratio would be $7: 3$.

\section{Results}

\subsection{Change in per-capita food demand from 1998 to 2012}

Overall, from 1998 to 2012, the national per-capita consumption of grain ration dropped from 182.2 to $115.4 \mathrm{~kg}$ of FEU, a drop of about $36.66 \%$. The per-capita consumption of grain-consuming livestock products rose from 174.6 to $258.4 \mathrm{~kg}$ of FEU, an increase of about $48 \%$ and the per-capita consumption of herbivorous livestock products rose from 13.2 to $17.7 \mathrm{~kg}$ of FEU, an increase of $34.09 \%$. The total consumption and rate of increase in products from grain-consuming livestock was greater than grain ration consumption for most of the period studied and these have now become the prime source of both calories and protein for consumers (Fig. 1a). The proportion of herbivorous livestock products in consumer diets was small from 1998 to 2012, but maintained a high growth rate from $3.57 \%$ to $4.52 \%$ (Fig. 1b), indicating the huge potential for substituting herbivorous livestock products for grain-consuming livestock products in this dynamic market.

From 1998 to 2012, per-capita consumption of the provincial grain ration decreased, especially in the 14 regions of eastern China and in Hainan, where per-capita consumption of grain ration was lower than the lowest level of 1998 (115 kg of FEU). The per-capita consumption of grain ration dropped the most in Jiangxi, Hunan and Hainan, decreasing by 110,94 and $93 \mathrm{~kg}$ of FEU, respectively. The per-capita consumption of grain ration in different regions showed a ladder-like distribution, with a gradual increase from the north-east to the south-west, and this was clearer in 2012 compared to 1998 (Fig. 2).

The per-capita consumption of grain-consuming livestock products in each region in 2012 had increased compared to 1998, and the consumption of grainconsuming livestock products in four regions (Sichuan, Chongqing, Guangdong and Hainan) exceeded the highest level in 1998 (344 kg of FEU). Per-capita consumption of grain-consuming livestock products in Hainan grew the most, an increase of $18 \mathrm{~kg}$ of FEU. Guangdong and Anhui had a significant growth at $12 \mathrm{~kg}$ of FEU and in Shanxi and Shaanxi it remained relatively stable. Overall, the 2012 consumption patterns in per-capita consumption of grainconsuming livestock products showed greater change in the south and the north, and less in the central region compared to 1998 (Fig. 3).

The per-capita consumption of herbivorous livestock products in Beijing, Tianjin, Henan and Guangdong had declined slightly by 2012 , whereas in other regions it had increased. Only in Tibet had the per-capita consumption of herbivorous livestock products exceeded the highest level in 1998. The largest increase in per-capita consumption of herbivorous livestock products was in Xinjiang and Tibet, with an increase of 38 and $36 \mathrm{~kg}$ of FEU, respectively. Consumption was higher per-capita in the west compared to the central and eastern regions, as expected. In mideastern China it was less in the center, and consumption in the south and north was higher (Fig. 4). This distribution of per-capita consumption of herbivorous livestock products was related to the distribution of grassland resources.

\subsection{Projection of the per-capita food consumption}

Based on the per-capita food consumption and the population projections for the regions (Table S3), the total consumption demand for various foods by 2020 was forecast. The total food demand in 2020 will be $670 \mathrm{Mt}$ of FEU, an increase of about $15 \%$ compared to the total food demand of $582 \mathrm{Mt}$ of FEU in 2012.

\subsubsection{Provincial demand for grain ration in 2020}

Overall, the total demand for grain ration in China in 2012 was $163 \mathrm{Mt}$ of FEU and is projected to be $169 \mathrm{Mt}$ of FEU in 2020, an increase of about $3.3 \%$. The average annual growth rate is about $0.36 \%$ from 2012 to 2020 , with Guangdong remaining the largest province for grain ration demand. Hebei, Jiangsu, Shandong, Henan, Hunan and Sichuan will be the provinces with the greatest demand, which will account for more than $35 \%$ of the total grain ration demand. Beijing, Tianjin, Hainan and Qinghai and Ningxia will remain as low grain ration demand areas of only $3.5 \%$ of the total national demand. Tibet will still have the lowest grain ration demand of only $0.5 \%$ of the total national demand (Table 1).

3.2.2 Provincial demand for grain-consuming livestock product in 2020

The total national demand for grain-consuming livestock 

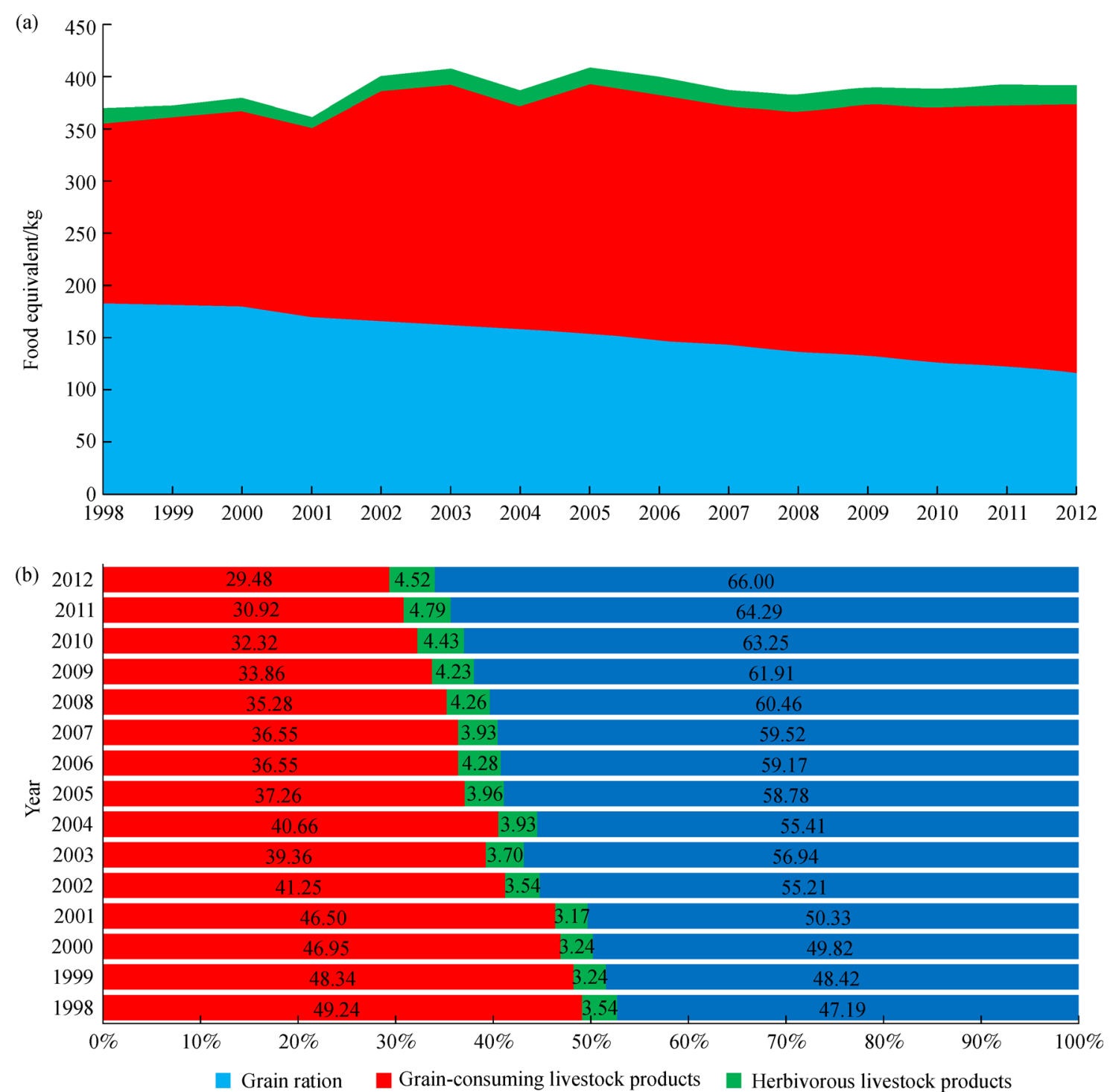

Fig. 1 Per-capita food consumption from 1998 to 2012

products in 2012 was $380.8 \mathrm{Mt}$ of FEU and is projected to be 457 Mt of FEU in 2020 (Table 1; Table S3), a 20\% increase at an average annual growth rate of $2.22 \%$ from 2012 to 2020. Guangdong has the largest demand for grain-consuming livestock products, and the proportion of demand is still increasing, from $12 \%$ in 2012 to $13 \%$ in 2020. Jiangsu, Shandong, Henan, Hubei, Hunan and Sichuan will be the top provinces in terms of the consumption of grain-consuming livestock products, although their share of total national demand will decline from 34\% in 2012 to 33\% in 2020. Tianjin, Hainan, Gansu, Qinghai, Ningxia and Xinjiang will have the lowest demand for grain-consuming livestock products, with their share of total national demand predicted to increase from $4.8 \%$ in 2012 to $5.0 \%$ in 2020 . Tibet still has the lowest predicted demand for grain-consuming livestock products, accounting for a mere $0.06 \%$ of total national demand (Table 1).
3.2.3 Provincial demand for herbivorous livestock products in 2020

The national demand for herbivorous livestock products in 2012 was 38.5 and is projected to be $44 \mathrm{Mt}$ of FEU in 2020 , an increase of $14 \%$ with an average annual growth rate of $1.15 \%$ from 2012 to 2020 . Guangdong has the most demand for herbivorous livestock products, but the proportion of demand will increase from 9\% in 2012 to $10.1 \%$ in 2020. Liaoning, Jiangsu, Sichuan, Xinjiang are the top ranked regions, and their proportion of the total national demand for herbivorous livestock products will rise from $22.3 \%$ in 2012 to $24.6 \%$ in 2020 . Hainan province has be the lowest demand, at only $0.07 \%$ of the national demand and Beijing, Tianjin, Shanxi, Tibet, Qinghai and Ningxia are the other regions with the lowest demand, and their proportion of total national demand will decline from $8.2 \%$ in 2012 to $7.1 \%$ in 2020 (Table 1). 

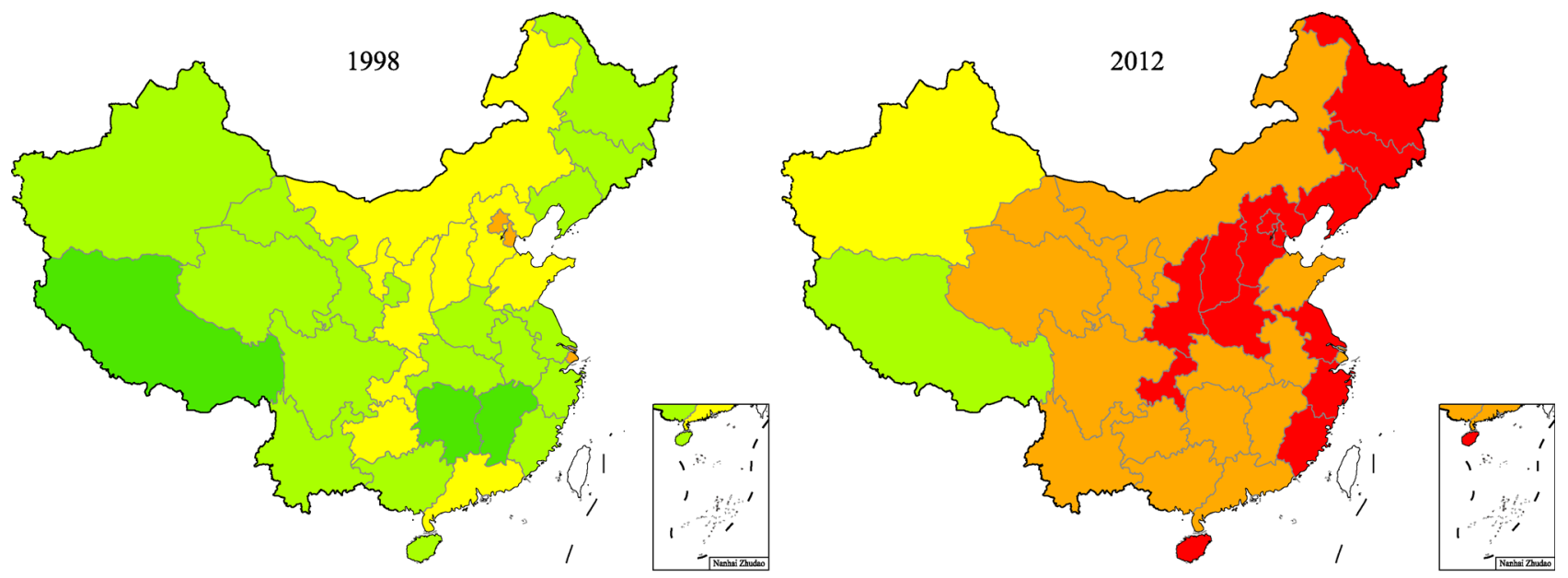

Less than $115 \mathrm{~kg} \square 115-150 \mathrm{~kg} \quad \square 150-190 \mathrm{~kg}$

$190-232 \mathrm{~kg} \square$ More than $232 \mathrm{~kg}$

The data is not available

Fig. 2 Comparison of per-capita consumption (kg of FEU) of grain ration in 1998 and 2012
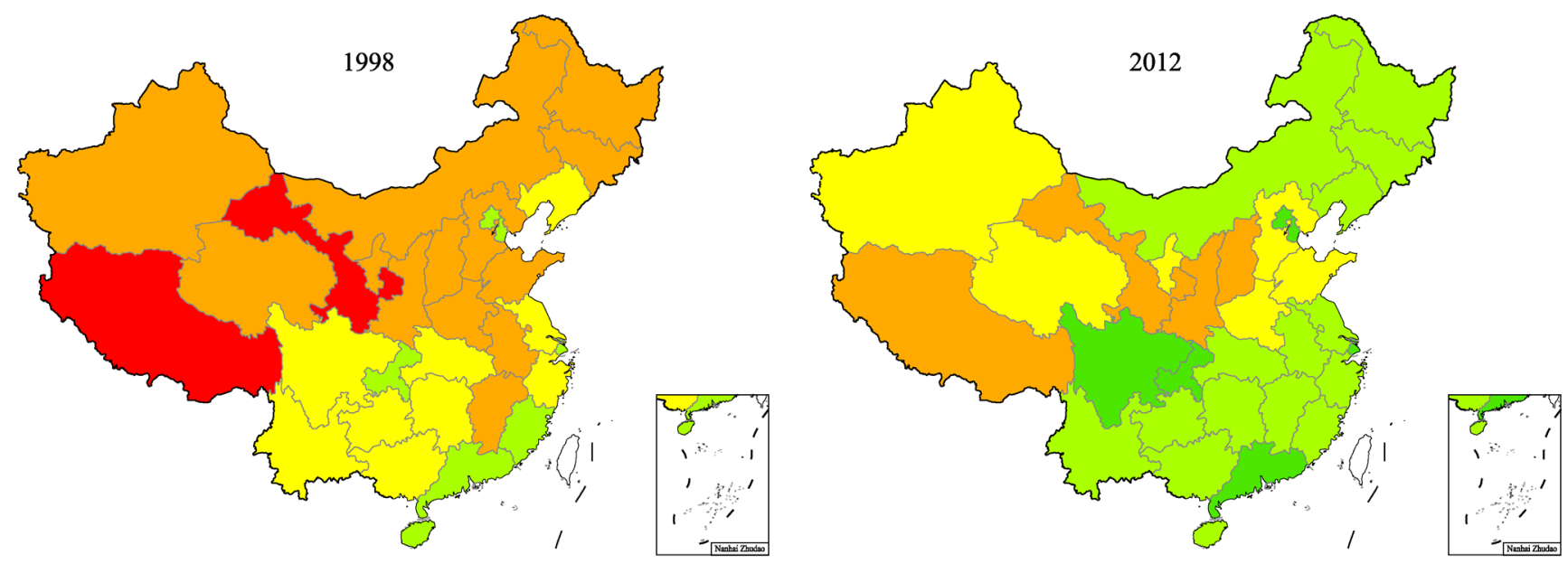

Less than $88 \mathrm{~kg}$

$88-180 \mathrm{~kg}$

$180-240 \mathrm{~kg}$

$240-324 \mathrm{~kg}$

More than $324 \mathrm{~kg}$

The data is not available

Fig. 3 Comparison of per-capita consumption (kg of FEU) of grain-consuming livestock products in 1998 and 2012

\subsection{Grassland agricultural production allocation}

Table 2 lists the ALEU 'red lines' of grain and forage that meet the provincial demand for the three categories of food in 2020. Taking into consideration the area of arable land needed in each region, and the proportion of land used for cultivated grassland and pasture-crop rotation, the actual area of arable land used for developing grassland agriculture at provincial scale was calculated. Overall, the traditional arable land still occupies the main part of the agricultural land use. The amount of ALEU that grain production requires is 6.4 times more than for forage production, which also embodied the first principle of ensuring grain ration safety. Sichuan requires the largest arable land area, accounting for $6.2 \%$ of the total national arable land area. Guangdong needs the largest area of the cultivated land for pasture-crop rotation and cultivated grassland to meet the demand for meat, while Ningxia 

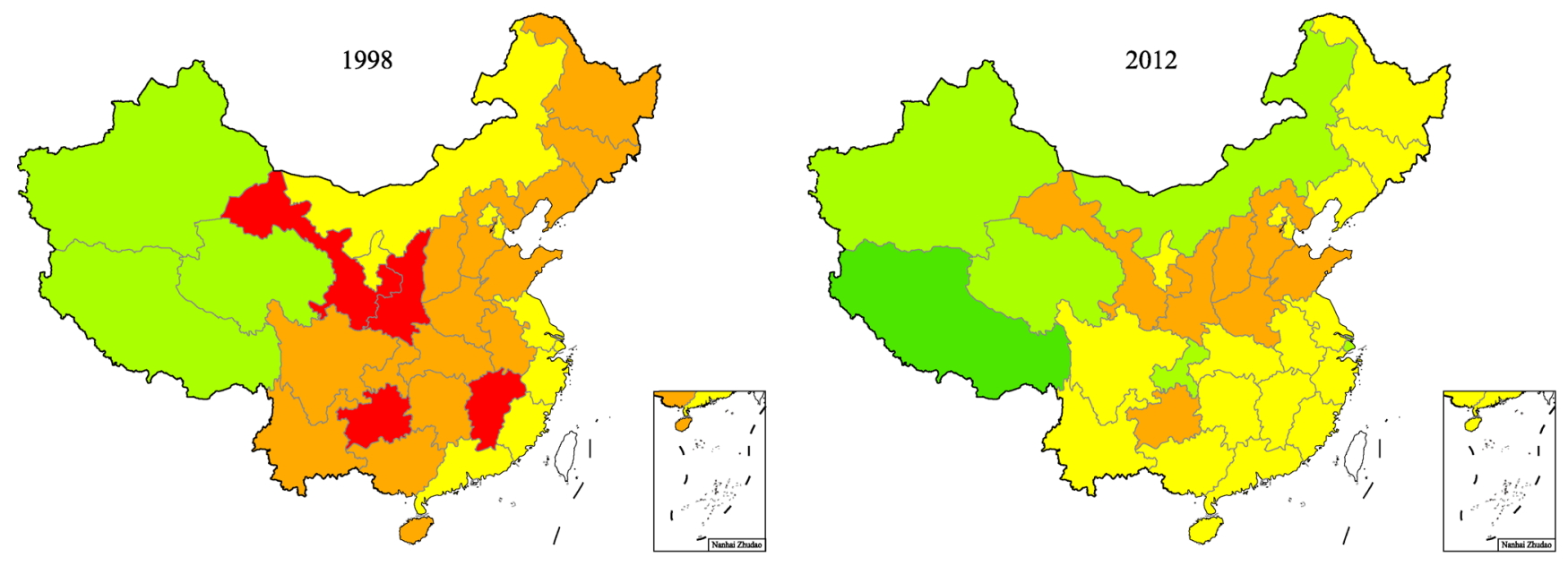

Less than $12 \mathrm{~kg}$

$12-20 \mathrm{~kg}$

$20-25 \mathrm{~kg}$

$50-120 \mathrm{~kg}$

More than $120 \mathrm{~kg}$

The data is not available needs the least. These statistics also reflect the need to make corresponding adjustment to agricultural land use allocation to meet future needs (Table 2).

\section{Discussion}

\subsection{Food demand law}

From 1998 to 2012, the per-capita consumption of grain ration generally decreased, the consumption of meat products rose and the rate of consumption of animal products was larger than the consumption of grain ration. The possible reasons for these changes are as follows. Firstly, with economic development, the dietary consumption patterns of consumers have shifted from cereal and vegetable to high-protein and high-fat food. Secondly, with large-scale and intensification of primary and secondary industry, livestock production costs have decreased steadily and the cost to consumers of purchasing animal products has decreased, so the desire and ability to purchase livestock products has increased since 1998.

However, the change in provincial per-capita consumption of food from 1998 to 2012 depended on the extent of income change in the different regions. The faster the incomes change, the faster the change in food consumption. Also, although the degree of food demand changed in response to income change, the elasticity of demand was different in the different regions and those with higher demand elasticity will have had greater changes in food demand, compared with areas with lower income elasticity.

\subsection{Neighborhood spatial spillover effect on land use}

Although the development of grassland agriculture saves a large proportion of arable land compared with the current agriculture system, comparison of the existing amount of arable land in each region with the farmland required for development of grassland agriculture indicated that there will still be some regions with insufficient arable land to satisfy their grain ration needs in 2020. In addition, to making full use of existing arable land, to ensure that there is no need to break fresh ground for new arable land, regions that cannot be self-sufficient in grain ration demand will need to import from the neighboring regions. Under the grassland agriculture system, the area of arable land that grain exporting regions need should also be included in the area of arable land used for grain ration. Figure 5 shows the arable land surplus or shortage under a grassland agriculture development scenario, compared with the existing resources. Figure 5 also indicates the regions where self-owned arable land cannot meet grain ration self-sufficiency (namely Shanghai, Zhejiang, Fujian and Guangdong, including Beijing and Tianjin). These areas are not only economically developed, with excellent living condition and rich dietary requirements for residents, but also have a high level of farmland urbanization. Thus, the grain supply capacity in these regions is poor. This is especially true in Guangdong province, where the current arable land area is only $2.83 \mathrm{Mhm}^{2}$ and the arable land gap will reach $4.13 \mathrm{Mhm}^{2}$ in 2020 , so arable land will be in extremely short supply. Hunan, Jiangxi, and Guizhou which are adjacent to these provinces will experience an arable land shortage and Ningxia, Qinghai and Tibet can 
Table 1 Food consumption (Mt of FEU) among regions in 2012 and 2020

\begin{tabular}{|c|c|c|c|c|c|c|}
\hline \multirow{2}{*}{ Region } & \multicolumn{2}{|c|}{ Grain ration } & \multicolumn{2}{|c|}{ Grain-consuming livestock product } & \multicolumn{2}{|c|}{ Herbivorous livestock product } \\
\hline & 2012 & 2020 & 2012 & 2020 & 2012 & 2020 \\
\hline$\overline{\text { Beijing }}$ & 0.17 & 0.20 & 0.56 & 0.77 & 0.05 & 0.06 \\
\hline Tianjin & 0.10 & 0.12 & 0.42 & 0.52 & 0.03 & 0.04 \\
\hline Hebei & 0.89 & 0.92 & 1.47 & 1.66 & 0.09 & 0.12 \\
\hline Shanxi & 0.46 & 0.47 & 0.70 & 0.79 & 0.04 & 0.04 \\
\hline Inner Mongolia & 0.29 & 0.30 & 0.88 & 0.83 & 0.15 & 0.17 \\
\hline Liaoning & 0.49 & 0.50 & 1.64 & 1.78 & 0.23 & 0.26 \\
\hline Jilin & 0.30 & 0.31 & 0.85 & 0.90 & 0.11 & 0.12 \\
\hline Heilongjiang & 0.35 & 0.37 & 1.17 & 1.21 & 0.17 & 0.19 \\
\hline Shanghai & 0.29 & 0.36 & 0.69 & 0.90 & 0.07 & 0.07 \\
\hline Jiangsu & 0.89 & 0.88 & 2.11 & 2.75 & 0.20 & 0.24 \\
\hline Zhejiang & 0.54 & 0.59 & 1.22 & 1.69 & 0.11 & 0.14 \\
\hline Anhui & 0.72 & 0.71 & 1.63 & 1.94 & 0.13 & 0.13 \\
\hline Fujian & 0.43 & 0.46 & 1.08 & 1.43 & 0.09 & 0.11 \\
\hline Jiangxi & 0.61 & 0.63 & 1.36 & 1.62 & 0.11 & 0.12 \\
\hline Shandong & 1.12 & 1.16 & 1.91 & 2.34 & 0.13 & 0.14 \\
\hline Henan & 1.27 & 1.25 & 1.76 & 2.17 & 0.11 & 0.10 \\
\hline Hubei & 0.75 & 0.71 & 1.81 & 2.03 & 0.14 & 0.15 \\
\hline Hunan & 0.86 & 0.87 & 2.09 & 2.31 & 0.15 & 0.16 \\
\hline Guangdong & 1.26 & 1.51 & 4.47 & 6.14 & 0.35 & 0.44 \\
\hline Guangxi & 0.55 & 0.58 & 1.57 & 1.88 & 0.20 & 0.21 \\
\hline Hainan & 0.10 & 0.10 & 0.34 & 0.42 & 0.03 & 0.03 \\
\hline Chongqing & 0.32 & 0.30 & 1.18 & 1.24 & 0.15 & 0.15 \\
\hline Sichuan & 1.07 & 0.99 & 3.21 & 3.46 & 0.32 & 0.34 \\
\hline Guizhou & 0.44 & 0.42 & 0.89 & 1.00 & 0.07 & 0.08 \\
\hline Yunnan & 0.59 & 0.62 & 1.39 & 1.79 & 0.11 & 0.14 \\
\hline Tibet & 0.07 & 0.08 & 0.02 & 0.03 & 0.05 & 0.06 \\
\hline Shaanxi & 0.44 & 0.45 & 0.62 & 0.72 & 0.08 & 0.09 \\
\hline Gansu & 0.44 & 0.43 & 0.46 & 0.55 & 0.07 & 0.07 \\
\hline Qinghai & 0.08 & 0.08 & 0.11 & 0.14 & 0.05 & 0.05 \\
\hline Ningxia & 0.08 & 0.09 & 0.10 & 0.16 & 0.04 & 0.05 \\
\hline Xinjiang & 0.37 & 0.41 & 0.38 & 0.50 & 0.24 & 0.30 \\
\hline
\end{tabular}

meet their own grain ration demand, but cannot export grain due to resource constraints. The remaining regions have different grain output capacities after the process of grassland agriculture development. Heilongjiang has the largest arable land surplus and will have more than 10 $\mathrm{Mhm}^{2}$ of surplus arable land in 2020 and be the largest grain producing area in China. All the situations discussed above have been confirmed by grain movement from the north to the south seen in recent years.

For the regions where there is a grain ration production gap, there are three principles that determine which regions should fill this gap. First, the principle of the shortest distance, namely the exporting regions should be close to the importing regions in order to avoid excessive transport costs and transport losses; Second, the principle of most to least abundance, that is, to try to select regions which have a large area of surplus arable land for to provide grain for export, in order to take full advantage of those regions with abundant arable land resources, while relieving undue pressure on the regions with arable land shortage. Third, the principle of only acting according to one's abilities, that is, before selecting an export regions, it should be 
Table 2 Arable land equivalent 'red line' and grassland agriculture product allocation

\begin{tabular}{|c|c|c|c|c|c|}
\hline \multirow{2}{*}{ Region } & \multicolumn{2}{|c|}{ Arable land equivalent 'red line'/Mhm ${ }^{2}$} & \multicolumn{3}{|c|}{ Grassland agriculture allocation/ $/ \mathrm{Mhm}^{2}$} \\
\hline & Grain & Forage & Arable land & Pasture-crop rotation & Cultivated grassland \\
\hline$\overline{\text { Beijing }}$ & 0.83 & 0.14 & 0.23 & 0.04 & 0.07 \\
\hline Tianjin & 0.55 & 0.10 & 0.44 & 0.04 & 0.03 \\
\hline Hebei & 2.76 & 0.29 & 3.97 & 0.10 & 0.09 \\
\hline Shanxi & 1.39 & 0.13 & 1.92 & 0.03 & 0.06 \\
\hline Inner Mongolia & 1.11 & 0.27 & 1.25 & 0.04 & 0.19 \\
\hline Liaoning & 2.04 & 0.46 & 1.86 & 0.16 & 0.14 \\
\hline Jilin & 1.14 & 0.22 & 0.89 & 0.08 & 0.07 \\
\hline Heilongjiang & 1.46 & 0.33 & 1.46 & 0.11 & 0.10 \\
\hline Shanghai & 1.23 & 0.17 & 0.24 & 0.04 & 0.05 \\
\hline Jiangsu & 3.33 & 0.53 & 3.95 & 0.13 & 0.16 \\
\hline Zhejiang & 2.14 & 0.32 & 1.92 & 0.06 & 0.16 \\
\hline Anhui & 2.50 & 0.33 & 3.11 & 0.08 & 0.10 \\
\hline Fujian & 1.73 & 0.26 & 1.33 & 0.05 & 0.13 \\
\hline Jiangxi & 2.19 & 0.29 & 2.25 & 0.05 & 0.15 \\
\hline Shandong & 3.63 & 0.39 & 3.49 & 0.14 & 0.12 \\
\hline Henan & 3.69 & 0.32 & 3.77 & 0.11 & 0.10 \\
\hline Hubei & 2.65 & 0.37 & 4.07 & 0.05 & 0.19 \\
\hline Hunan & 3.13 & 0.41 & 2.99 & 0.05 & 0.21 \\
\hline Guangdong & 6.52 & 1.15 & 2.83 & 0.28 & 0.34 \\
\hline Guangxi & 2.22 & 0.41 & 3.56 & 0.05 & 0.20 \\
\hline Hainan & 0.44 & 0.08 & 0.56 & 0.01 & 0.04 \\
\hline Chongqing & 1.41 & 0.31 & 1.40 & 0.05 & 0.09 \\
\hline Sichuan & 3.97 & 0.71 & 4.19 & 0.05 & 0.49 \\
\hline Guizhou & 1.41 & 0.19 & 4.03 & 0.03 & 0.06 \\
\hline Yunnan & 2.26 & 0.33 & 3.02 & 0.04 & 0.17 \\
\hline Tibet & 0.19 & 0.07 & 0.20 & 0.01 & 0.05 \\
\hline Shaanxi & 1.31 & 0.17 & 1.83 & 0.04 & 0.08 \\
\hline Gansu & 1.17 & 0.13 & 1.66 & 0.02 & 0.09 \\
\hline Qinghai & 0.25 & 0.07 & 0.40 & 0.01 & 0.05 \\
\hline Ningxia & 0.28 & 0.07 & 0.30 & 0.01 & 0.05 \\
\hline Xinjiang & 1.17 & 0.37 & 1.16 & 0.06 & 0.26 \\
\hline
\end{tabular}

determined if the provincial surplus of arable land can meet the actual demand from the importing regions. If this is not easily achieved or is impossible, then importing from several neighboring regions at the same times will be necessary in order to meet the demand according to the neighborhood spatial spillover effect ${ }^{[24]}$. Based on these three principles, Beijing and Tianjin may import grain from Hebei, Shanghai can import from Jiangsu, and Zhejiang and Fujian can import from Anhui. Given that it has the largest grain demands, Guangdong needs to import from Guangxi, Guizhou and Hubei at the same time (Fig. 5), and the proportion of imports from the three provinces will depend on the amount of their surplus arable land.
4.3 Development of grassland agriculture production regional allocation

The distribution of grassland agricultural production varies greatly among the regions of China. According to the forage productivity of each region, the 31 regions can be divided into three priority groups for grassland agriculture development. The regions with the higher need for forage production are set as first priority, the regions with some requirement for forage production are set as the second priority, and the regions with the lowest need for forage production are set as the third priority, as shown in Fig. 6.

The first priority group is located in traditional 


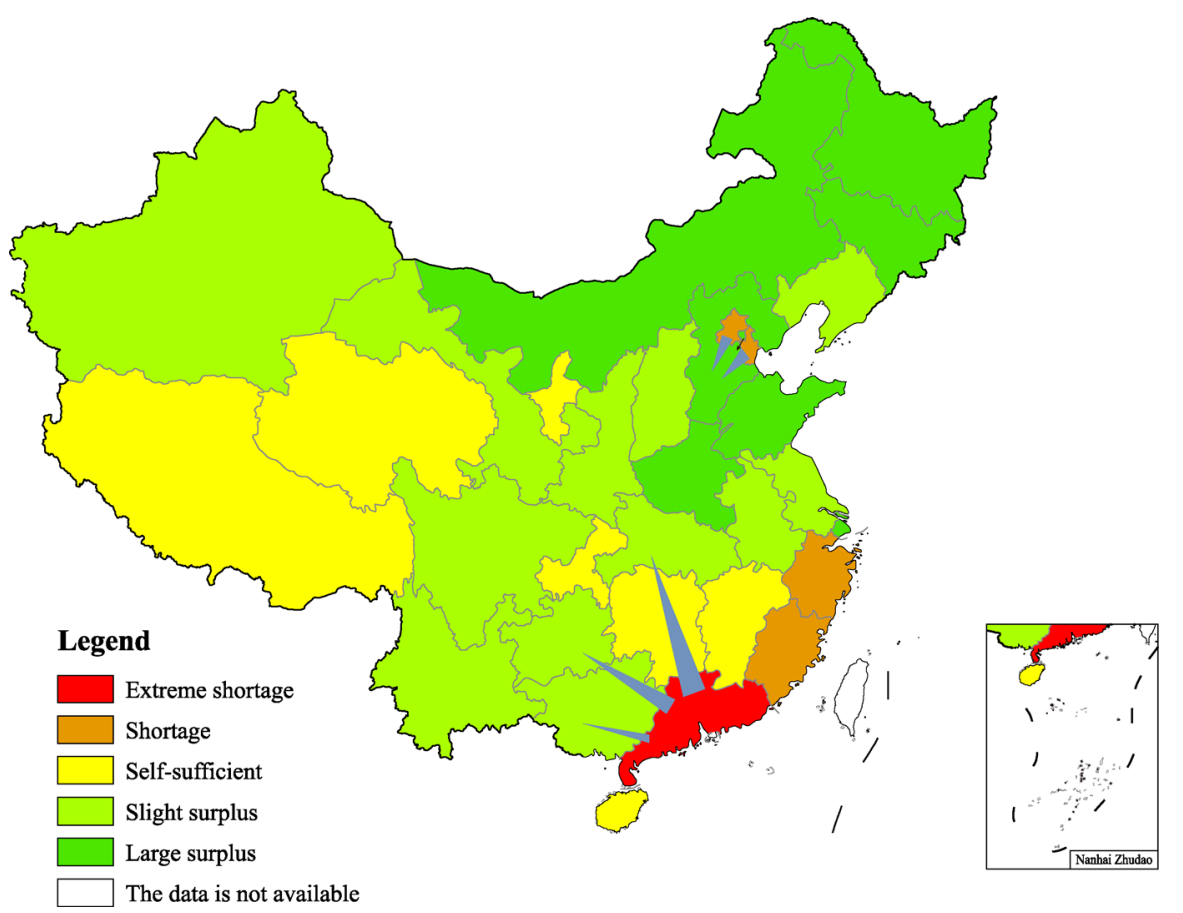

Fig. 5 Spatial spillovers in arable land among regions for grassland agriculture development

agricultural area of China (Fig. 6). This area has a huge population, rapid economic development, and high demand for animal food. Less grass-planting is practiced so the vast majority of animals are fed grain ${ }^{[28]}$. Therefore, the traditional farmland agriculture in these areas has difficulty in guaranteeing sustainable food security, so a change in the agricultural structure and the development of grassland agriculture is needed ${ }^{[29]}$.

The second priority group is close to the farmingpastoral transitional zone of China (Fig. 6). The economic development is lower than the first priority group and higher than the third group. The demand for animal food is relatively small, and the pressure for feed grain is relatively small. In some areas, a mixture of cropping and grain- and grass-fed livestock production has developed to a certain extent. In some areas, it is necessary to develop grassland agriculture to improve the agricultural practices ${ }^{[30]}$.

The third priority group is located in the traditional pastoral areas of China (Fig. 6). Due to the characteristics of climate, natural resources and folk customs, grassland animal husbandry occupies an important position in the current agricultural practices. Coupled with its relatively low level of economic development, and living standards, the demand for animal food is less than in the traditional agricultural and farming-pastoral transitional zones, and grain demand is lower. However, due to limited resource abundance in these areas grasslands and pastures which constitute an important part of grassland agriculture in these areas, have been seriously degraded. Therefore in these areas, there is an urgent need to vigorously protect the ecological environment and to maintain an ecological balance $^{[31-33]}$.
Grassland is a very important component of agricultural systems in developed countries around the world. The USA has a relatively complete grassland agricultural system, using not only the ecological functions of grassland agriculture to produce more animal products with a smaller ecological environmental cost, but also in recent years has begun to research annual cereal grasses as biofuels instead of annual grain ${ }^{[5,16,34]}$. As a small country of only $37000 \mathrm{~km}^{2}$, the Netherlands two-thirds of the arable land is laid down to plant forage and is ranked second in the world for quantity of agricultural product exports. Japan has also proposed raising forage for feeding ruminant livestock as the best use of limited land, and increased grassland farming areas by $91 \%$ in the $1970 \mathrm{~s}^{[35]}$. New Zealand, Germany, Canada, Russia, Australia and other countries, have introduced measures such rational use of natural grassland, the use of modern fencing, the development of cultivated grassland, have developed different grassland agricultural models in accordance with the characteristic resources in their territories. In China, the cultivated grassland, which is the index of the level of grassland modernization, accounts for only $2 \%$ of the total grassland area, compared with $69 \%$ in New Zealand, Australia at 58\%, Western Europe and Nordic countries at more than $50 \%$ and the USA at $13 \%$. The gap is obvious and the full implementation of grassland agriculture in China has a long way to go.

\section{Conclusions}

From 1998 to 2012, with economic development, the 


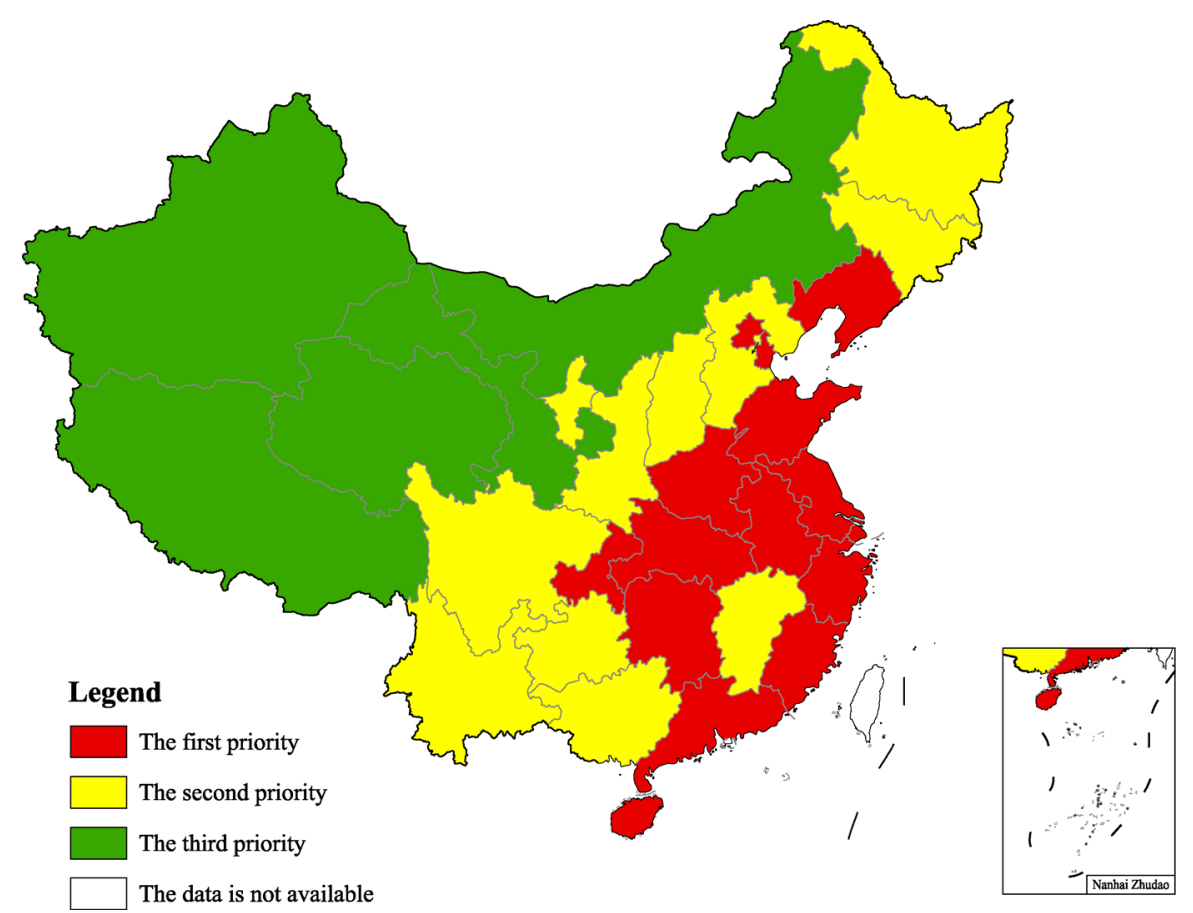

Fig. 6 Priorities for developing grassland agriculture

dietary consumption patterns of consumers have shifted from cereal and vegetable to high-protein and high-fat food. The consumption of the grain-consuming livestock products had accounted for $66 \%$ of the total national food consumption in 2012 (Fig. 1b). The grain-consuming livestock products had become the prime source of both calories and protein for consumers, even the herbivorous livestock products indicated the huge potential for substituting herbivorous livestock products for grainconsuming livestock products in this dynamic market. The total food demand in 2020 will have an increase of about 15\% compared to the total food demand in 2012 . There is a big gap in the calories and protein consumption derived from livestock products.

Spatial econometrics analysis showed that the extent of income change, the elasticity of demand and resource constraints decided the different of food consumption in the different regions, which is the important basis for adjusting the industrial layout and ensuring food safety. Grassland agriculture, with its main outputs based on vegetative growth rather than reproductive growth of plants, is more efficient as well as more ecological than the arable agriculture only relying on grain production. Grassland agriculture is bound to gradually replace the traditional arable agriculture in China, becoming the main stream of the agriculture of China, and thus to mitigate the problems in China's agricultural development.

With the demand by the society and the unprecedented support from the national government, China's modern pratacultural science has a never-had opportunity for its develop. Comprehensive consideration of grassland, livestock and arable based on the spatial and temporal analysis for food demand, a new short-term plan for development of grassland agriculture in China was proposed. The traditional agricultural area of China is set as the first priority group (Fig. 6) by changing the farming system into grassland agriculture. The farming-pastoral transitional zone is designed as the second priority group (Fig. 6) by developing a mixture system of cropping and grain- and grass-fed livestock production. The traditional pastoral areas is considered as the third priority group (Fig. 6), aiming to vigorously protect the ecological environment and to maintain an ecological balance as main target.

Supplementary materials The online version of this article at http://dx. doi.org/10.15302/J-FASE-2017140 contains supplementary materials (Tables S1-S3 ).

Acknowledgements The authors appreciate the English editorial work of Boya Lin, a master candidate at University of Florida. Thanks specially go to the anonymous reviewer who kindly helped the authors to amend the manuscript to an acceptable level of English. The research was supported by the key project "Study of the Dynamic Market Equilibrium in Substituting Beef and Mutton for Pork" by the State Key Laboratory of Grassland Agroecosystems (SKLGAE201502) and Program for Changjiang Scholars and Innovative Research Team in University (IRT13019).

Compliance with ethics guidelines Huilong Lin, Ruichao Li, Yifan Liu, 
Jingrong Zhang, and Jizhou Ren declare that they have no conflict of interest or financial conflicts to disclose.

This article does not contain any studies with human or animal subjects performed by any of the authors.

\section{References}

1. CFS. Making a difference in food security and nutrition. http://www. fao.org/cfs/en/, 2014-11-18

2. Fan M, Shen J, Yuan L, Jiang R, Chen X, Davies W J, Zhang F. Improving crop productivity and resource use efficiency to ensure food security and environmental quality in China. Journal of Experimental Botany, 2012, 63(1): 13-24

3. Wong J, Huang Y J. China's food security and its global implications. China: An International Journal, 2012, 10(1): 113124

4. Lu Q S, Xu B, Liang F Y, Gao Z Q, Ning J C. Influences of the Grain-for-Green project on grain security in southern China. Ecological Indicators, 2013, 34(11): 616-622

5. Wedin W F, Fales S L. Grassland: quietness and strength for a new American agricultural. New York: American Society of Agronomy, 2009

6. Huang J K, Yang J, Chou H G. Thinking of Chinese food security strategy in new period. Issues in Agricultural Economy\& Technology, 2012, 23(3): 4-8 (in Chinese)

7. Huang J K. Chinese food security problem. Chinese Rural Economy, 2004, 20(10): 4-10 (in Chinese)

8. Lin H L, Li R C, Jin C Y, WangWei M H, Ren J Z C, Wei M H, Ren J Z. China's new problems of food security revealed by the Food Equivalent Unit. Frontiers of Agricultural Science and Engineering, 2014, 1(1): 69-76

9. He X R, Xiao H P, Zhu Q R. Chinese food security assess at the nation level. Chinese Rural Survey, 2004, 25(6):14-22 + 80 (in Chinese)

10. Zheng F T. The adjustment from food security system to food safety system - the strategic transfer faced by Chinese food production systems. Study of Finance and Economics, 2003, 48(2): 70-75 (in Chinese)

11. Li Y T. A strategy of ensure food security - develop green protein pasture and reduce grain feed animal. Pratacultural Science, 2009, 26(2): 1-4 (in Chinese)

12. Ren J Z. Current condition and productive potential of grasslands in southern China. Acta Prataculturae Sinica, 1999, 8(1): 23-31 (in Chinese)

13. Huangpu J Y, Mao F X, Lu X S. Analysis of grassland resources in southwest China. Acta Prataculturae Sinica, 2012, 21(1): 75-82 (in Chinese)

14. Huang Q. Changes of food supply-demand pattern and strategic allocation of sunlight, warmth and water resources in China. Acta Prataculturae Sinica, 2010, 19(2): 1-6 (in Chinese)

15. Li R C, Lin H L. Analysis of the problem of food shortage in Southern China based on the study of two grassland ecologicaleconomic regions. Acta Prataculturae Sinica, 2015, 24(1): 4-11 (in Chinese)

16. Research Group of. Strategies to ensure grassland ecological and food security in China. Strategies and policies for the ecological and food security of China's grassland. Engineering and Science, 2016, 18(1): 8-16 (in Chinese)

17. Ren J Z, Lin H L, Hou X Y. Developing the agro-grassland system to insure food security of China. Scientia Agricultura Sinica, 2007, 40(3): 614-621 (in Chinese)

18. Ren J Z, Xu G, Li X L, Lin H L, Tang Z. Trajectory and prospect of China's prataculture. Chinese Science Bulletin, 2016, 61: 178-192 (in Chinese)

19. Jin C Y, Lin H L. Adjustment of Chinese agricultural structure from the perspective of grain production consumption of meat in China. Pratacultural Science, 2016, 33(2): 330-337 (in Chinese)

20. Tang Y T, Lin H L. Evaluation of food security and new developmental routing selection. Acta Prataculturae Sinica, 2015, 24(7): 189-196 (in Chinese)

21. Tang $Y$ T, Lin H L. An immature suggestion for grassland agriculture innovation model on food security. Journal of Agricultural Science and Technology, 2012, 14(5): 7-14 (in Chinese)

22. Ren J Z, Lin H L. Arable land equivalent unit and potential food productivity of land resources in China. Acta Prataculturae Sinica, 2006, 15(5): 1-10 (in Chinese)

23. Ren J Z, Hou F J. Change traditional thinking about food grain production and use food equivalent in yield measurement. Acta Prataculturae Sinica, 1999, 8(S1): 55-75 (in Chinese)

24. James L, Kelley P. Introduction to spatial econometrics. Florida: CRC Press of Taylor \& Francis group, 2009

25. Lin J. Provincial difference of urbanization level in terms of population since 2000 - Based on emendation of statistical data. Planning Study, 2010, 34(3): 48-56 (in Chinese)

26. Department of the Ministry of Agriculture Development Program. New century of Chinese agriculture outlook - Ministry of Agriculture and rural economic develop planning corpus in future ten years. Beijing: China Agriculture Press, 2002 (in Chinese)

27. Ren J Z. Chinese traditional agricultural construct need to make change-Hidden danger after grain productive increasing among nine years. Acta Prataculturae Sinica, 2013, 22(3): 1-5 (in Chinese)

28. Li R C, Lin H L. Analysis of the problem of food shortage in Southern China based on the study of two grassland ecological economic regions. Acta Prataculturae Sinica, 2015, 24(1): 4-11 (in Chinese)

29. Ren J Z, Lin H L. Promoting prataculture development in arable region to ameliorate the farming system and insure food security in China. Acta Prataculturae Sinica, 2009, 18(5): 1-9 (in Chinese)

30. Li F, Lin H L, Chang S H. Emergy evaluation on the cropping mode and the cropping-breeding coupled mode in the ecotone between farming and pasturing area. Acta Agrestia Sinica, 2007, 15(4): $322-$ 326 (in Chinese)

31. Li R C, Jin C Y, Lin H L. Grassland agriculture substitution strategy: Based on the research of the six pastoral areas. Acta Agrestia Sinica, 2014, 22(7): 685-690 (in Chinese)

32. Li R C, Lin H L. Impact of returning farmland to grassland on Chinese food security - a case study of Gansu Province. Acta Agrestia Sinica, 2014, 22(1): 22-26 (in Chinese)

33. Research Group of Strategies to Ensure Grassland Ecological and 
Food Security in China. Strategies and policies for the ecological and food security of China's grassland. Journal of Chinese Engineering Sciences, 2016, 18(1): 8-16 (in Chinese)

34. Zhang M H. A brief discussion on grassland agricultural system.
Acta Agrectir Sinica, 1994, 2(1): 83-88 (in Chinese)

35. Hou X Y. Grassland agricultural system construction and the future development direction of China. Journal of Finance and Economics Theory, 2009, 16(2): 33-37 (in Chinese) 